\title{
Angka Kasus Kekerasan dalam Rumah Tangga di Kota Manado Tahun 2018-2019
}

\author{
Rebennia N. T. Tumewu, ${ }^{1}$ Djemi Tomuka, ${ }^{2}$ Erwin G. Kristanto ${ }^{2}$
}

\author{
${ }^{1}$ Program Studi Pendidikan Dokter Fakultas Kedokteran Universitas Sam Ratulangi, Manado, \\ Sulawesi Utara, Indonesia \\ ${ }^{2}$ Bagian Ilmu Kedokteran Forensik dan Medikolegal Fakultas Kedokteran Universitas Sam \\ Ratulangi, Manado, Sulawesi Utara, Indonesia \\ Email: rebenniatumewu22@gmail.com
}

\begin{abstract}
Domestic violence is universal and can occur regardless of age, profession, economic level or education of the victims. According to World Health Organization, 1 in 3 women in the world had experienced physical or sexual violence. In addition, according to the British Crime Survey, $1 / 3$ of victims of domestic violence were male. This study was aimed to obtain the number of domestic violence cases in Manado during 2018-2019. This was a retrospective and descriptive study with a cross-sectional design using secondary data of domestic violence case reports at Polresta Manado regarding domestic violence in Manado 2018-2019. The results showed that there were 111 cases of domestic violence in 2018-2019 in Manado. Most cases occurred at Sario District (14 cases; 13\%) dominated by physical violence (78 cases; $70 \%$ ), committed by male perpetrators (101 cases; 91\%), husbands of the victims (101 cases; 91\%), and age group of 15-24 years (43 cases; $39 \%$ ). In conclusion, there was a fluctuation in the number of domestic violence cases; an increase of 51.3\% comparing to the number of cases in 2012-2013 and a decrease of $27.4 \%$ comparing to the number of cases in 2015-2016.
\end{abstract}

Keywords: domestic violence

\begin{abstract}
Abstrak: Kekerasan dalam rumah tangga (KDRT) merupakan hal yang universal dan dapat terjadi tanpa memandang usia, profesi, tingkat ekonomi, maupun pendidikan dari korban. Menurut data WHO (World Health Organization), 1 dari 3 perempuan di dunia pernah mengalami kekerasan fisik maupun seksual. Selain itu, menurut British Crime Survey, 1/3 korban KDRT ialah laki-laki. Penelitian ini bertujuan untuk mendapatkan angka kasus KDRT di Kota Manado tahun 2018-2019. Jenis penelitian ialah deskriptif retrospektif dengan desain potong lintang. Data sekunder yaitu laporan kasus KDRT di Polresta Manado mengenai KDRT di Kota Manado pada tahun 20182019. Hasil penelitian mendapatkan, kasus KDRT pada tahun 2018-2019 di Kota Manado berjumlah 111 kasus, paling banyak terjadi di Kecamatan Sario (14 kasus; 13\%), didominasi oleh jenis kekerasan fisik (78 kasus; 70\%), pelaku berjenis kelamin laki-laki (101 kasus; 91\%), yang merupakan suami korban (101 kasus; 91\%), dan paling sering dialami oleh kelompok usia 15-24 tahun (43 kasus; 39\%). Simpulan penelitian ini ialah terdapat fluktuasi angka kasus KDRT dibandingkan jumlah kasus pada tahun 2012-2013 yaitu terjadi peningkatan sebanyak 51,3\% dan terjadi penurunan $27,4 \%$ bila dibandingkan dengan jumlah kasus pada tahun 2015-2016.
\end{abstract}

Kata kunci: kekerasan dalam rumah tangga (KDRT)

\section{PENDAHULUAN}

Kekerasan dalam rumah tangga (KDRT) adalah setiap perbuatan terhadap seseorang, yang berakibat timbulnya kesengsaraan atau penderitaan secara fisik, seksual, psikologis, dan atau penelantaran rumah tangga termasuk ancaman untuk melakukan perbuatan, pemaksaan atau perampasan kemerdekaan secara melawan hukum dalam lingkup rumah tangga. ${ }^{1}$ Hasil penelitian seringkali 
menunjukkan peningkatan kejadian KDRT meski pada banyak kasus, korbannya bungkam karena tidak tahu harus dimana harus melapor, kerap dianggap mempermalukan keluarga, atau seringkali dituduh sebagai biang keladi rusaknya rumah tangga. Adanya alasan-alasan inilah yang mempersulit dalam pengumpulan data dan penyelesaian masalah oleh pihak berwajib.

Studi dari berbagai negara menunjukkan angka kejadian KDRT berkisar cukup tinggi yaitu antara $15-71 \% .^{2}$ Komisi Nasional Anti Kekerasan Terhadap Perempuan (Komnas Perempuan) mencatat dalam Catatan Tahunan (CATAHU) tahun 2017, jumlah kasus kekerasan terhadap perempuan dilaporkan meningkat sebesar $74 \%$ dari tahun sebelumnya dan jenis kekerasan yang paling menonjol ialah KDRT/RP (ranah personal). Bahkan pada tahun 2018, CATAHU menyorot ancaman KDRT yang semakin berujung pada pembunuhan dengan tidak memandang status sosial dari masyarakat. ${ }^{3}$ Di Sulawesi Utara, berdasarkan penelitian yang dilakukan di Rumah Sakit Bhayangkara Manado pada tahun 2010, terdapat sebanyak 57 kasus dan pada tahun 2011 terjadi peningkatan sebesar 359, sekitar $65 \%$. $^{2}$ Pada tahun 2015-2016 di Rumah Sakit Bhayangkara Tingkat III Manado, kasus KDRT masih termasuk salah satu bagian besar dari kasus forensik klinik yang masuk. ${ }^{4}$

Kekerasan dalam rumah tangga termasuk dalam wilayah pelayanan kedokteran forensik klinik yang semakin luas seiring bertambahnya waktu. Pelayanan kedokteran forensik sebagian besar dilakukan oleh dokter umum karena terbatasnya jumlah spesialis di bidang forensik. Salah satu peran dokter umum dalam pelayanan kedokteran forensik ialah tindak pidana hidup yang termasuk di dalamnya ialah KDRT ${ }^{5}$ Hal-hal tersebut yang mendorong penulis untuk meneliti mengenai angka kejadian KDRT di Kota Manado periode 2018-2019.

\section{METODE PENELITIAN}

Penelitian yang dilakukan bersifat deskriptif retrospektif dengan menggunakan data sekunder yaitu laporan kasus KDRT di
Polisi Resor Kota (Polresta) Manado mengenai KDRT di Kota Manado pada tahun 2018-2019. Sampel penelitian ialah semua data lengkap kasus KDRT yang terlapor di Polresta Manado pada periode tahun 2018-2019. Variabel penelitian ialah jumlah kasus berdasarkan bentuk kekerasan, jenis kelamin korban dan pelaku, kelompok usia korban, tingkat pendidikan pelaku, status pekerjaan korban, hubungan korban dengan pelaku, status pendampingan korban saat pelaporan di Polresta, selang waktu antara kejadian dan pelaporan, dan daerah tempat kejadian menurut kecamatan.

Penelitian ini telah mendapat persetujuan dari Komisi Etik Penelitian Kesehatan RSUP Prof. Dr. R. D. Kandou Manado, dengan nomor keterangan layak etik yaitu No. 089/EC/KEPK-KANDOU/X/2020.

\section{HASIL PENELITIAN}

Data yang diperoleh di Polresta Manado mengenai jumlah kasus KDRT pada tahun 2018-2019 sebanyak 111 kasus terlapor, terdiri dari 66 kasus terlapor pada tahun 2018 dan 45 kasus pada tahun 2019.

Tabel 1 menunjukkan jumlah kasus berdasarkan bentuk kekerasan dalam rumah tangga yang terjadi berupa kekerasan fisik berjumlah 78 kasus (70\%), kekerasan seksual tidak ada kasus (0\%), kekerasan fisik dan seksual tidak ada kasus (0\%), kekerasan psikis tidak ada kasus $(0 \%)$, dan penelantaran rumah tangga dengan jumlah 33 kasus $(30 \%)$.

Tabel 2 memperlihatkan data jumlah kasus KDRT berdasarkan jenis kelamin korban yaitu didominasi oleh perempuan dengan jumlah sebanyak 101 kasus (91\%). Jumlah korban berjenis kelamin laki-laki sebanyak 10 kasus (9\%) dengan jenis kekerasan fisik dan korban yang mengalami penyakit tertentu atau difabel.

Tabel 3 memperlihatkan bahwa jenis kelamin pelaku didominasi oleh pelaku berjenis kelamin laki-laki dengan jumlah 101 kasus (91\%) sedangkan pelaku dengan jenis kelamin perempuan berjumlah 10 kasus $(9 \%)$. 
Tabel 1. Jumlah kasus KDRT di Kota Manado tahun 2018-2019 menurut bentuk KDRT

\begin{tabular}{lcc}
\hline \multicolumn{1}{c}{ Bentuk KDRT } & Jumlah & \% \\
\hline Kekerasan Fisik & 78 & 70 \\
Kekerasan Seksual & 0 & 0 \\
Kekerasan Fisik dan Seksual & 0 & 0 \\
Kekerasan Psikis & 0 & 0 \\
Penelantaran Rumah Tangga & 33 & 30 \\
Total & 111 & 100 \\
\hline
\end{tabular}

Tabel 2. Jumlah kasus KDRT di Kota Manado tahun 2018-2019 menurut jenis kelamin korban

\begin{tabular}{lcc}
\hline Jenis Kelamin & Jumlah & \% \\
\hline Laki-laki & 10 & 9 \\
Perempuan & 101 & 91 \\
Total & 111 & 100 \\
\hline
\end{tabular}

Tabel 3. Jumlah kasus KDRT di Kota Manado Tahun 2018-2019 menurut jenis kelamin pelaku

\begin{tabular}{lcc}
\hline Jenis kelamin & Jumlah & \% \\
\hline Laki-laki & 101 & 91 \\
Perempuan & 10 & 9 \\
Total & 111 & 100 \\
\hline
\end{tabular}

Tabel 4 memperlihatkan bahwa kelompok usia yang paling banyak menjadi korban dari kasus KDRT ialah kelompok usia 15-24 tahun (39\%) diikuti oleh kelompok usia 2544 tahun (32\%), kelompok usia 5-14 tahun (17\%), kelompok usia 45-64 tahun (12\%). Tidak ada laporan kasus pada kelompok usia $<5$ tahun dan $>65$ tahun. Terdapat 19 korban berusia 14 tahun dan berstatus sebagai istri dari pelaku. Korban dan pelaku dinikahkan berdasarkan kepercayaan dan adat istiadat yang berlaku di daerah mereka.

Tabel 4. Jumlah kasus KDRT di Kota Manado tahun 2018-2019 menurut kelompok usia

\begin{tabular}{lcc}
\hline $\begin{array}{c}\text { Kelompok } \\
\text { usia (tahun) }\end{array}$ & Jumlah & \% \\
\hline$<5$ & 0 & 0 \\
$5-14$ & 19 & 17 \\
$15-24$ & 43 & 39 \\
$25-44$ & 36 & 32 \\
$45-64$ & 13 & 12 \\
$>65$ & 0 & 0 \\
Total & 111 & 100 \\
\hline
\end{tabular}

Tabel 5 memperlihatkan bahwa berdasarkan tingkat pendidikan, yang terbanyak menjadi pelaku kasus KDRT ialah yang memiliki tingkat pendidikan SLTP (45\%) dan diikuti oleh tingkat pendidikan SLTA (42\%), tingkat pendidikan di bawah SD atau sederajat (5\%), tingkat pendidikan Diploma (3\%), tingkat pendidikan Sarjana (3\%), dan yang paling sedikit pada tingkat pendidikan Pascasarjana (2\%).

Tabel 5. Jumlah kasus KDRT di Kota Manado tahun 2018-2019 menurut tingkat pendidikan

\begin{tabular}{lcc}
\hline $\begin{array}{c}\text { Tingkat } \\
\text { pendidikan }\end{array}$ & Jumlah & \% \\
\hline $\begin{array}{l}\text { Di bawah SD/ } \\
\text { sederajat }\end{array}$ & 6 & 5 \\
SLTP & 50 & 45 \\
SLTA & 47 & 42 \\
Diploma & 3 & 3 \\
Sarjana & 3 & 3 \\
Pascasarjana & 2 & 2 \\
Total & 111 & 100 \\
\hline
\end{tabular}

Tabel 6 memperlihatkan bahwa korban yang paling banyak mengalami KDRT ialah korban yang tidak bekerja (51\%) dibandingkan korban yang bekerja (49\%).

Tabel 6. Jumlah kasus KDRT di Kota Manado tahun 2018-2019 menurut status pekerjaan

\begin{tabular}{lcc}
\hline Status pekerjaan & Jumlah & $\mathbf{\%}$ \\
\hline Bekerja & 54 & 49 \\
Tidak Bekerja & 57 & 51 \\
Total & 111 & 100 \\
\hline
\end{tabular}

Tabel 7 memperlihatkan bahwa yang paling banyak menjadi korban kasus KDRT ialah istri pelaku $(91 \%)$, namun terdapat 
juga suami pelaku (9\%) yang menjadi korban. Untuk korban yang memiliki hubungan anak, mertua, saudara, asisten rumah tangga, dan lainnya ditemukan tidak adanya laporan $(0 \%)$.

Tabel 8 memperlihatkan bahwa saat pelaporan, korban paling banyak didampingi oleh keluarga sendiri (63\%), diikuti oleh korban yang didampingi oleh orang lain selain keluarga (16\%), didampingi oleh pengacara $(12 \%)$, didampingi oleh orang lain $(16 \%)$; tidak ada korban yang tidak didampingi saat pelaporan $(0 \%)$.

Tabel 9 memperlihatkan bahwa umumnya korban melapor kurang dari satu minggu setelah kasus KDRT terjadi sebanyak 92 kasus (83\%), dan yang melapor lebih dari satu minggu setelah kejadian berjumlah 19 kasus (17\%). Hal ini menunjukkan bahwa banyak korban dari kasus KDRT mulai menyadari betapa pentingnya untuk segera melaporkan kasus yang dialaminya.

Tabel 10 memperlihatkan bahwa kasus KDRT paling banyak terjadi di Kecamatan Sario (13\%), diikuti oleh Kecamatan Malalayang dan Singkil (masing-masing 11\%), Kecamatan Wenang, Wanea dan dan Tuminting (masing-masing 10\%), Kecamatan Tikala (9\%), Kecamatan Bunaken dan Paal Dua (masing masing 7\%), dan yang paling sedikit terjadi di Kecamatan Mapanget dan Bunaken Kepulauan (masing-masing 6\%).

Tabel 7. Jumlah kasus KDRT di Kota Manado tahun 2018-2019 menurut hubungan korban dengan pelaku

\begin{tabular}{lcc}
\hline \multicolumn{1}{c}{ Hubungan } & Jumlah & \% \\
\hline Suami & 10 & 9 \\
Istri & 101 & 91 \\
Anak & 0 & 0 \\
Mertua & 0 & 0 \\
Saudara & 0 & 0 \\
Asisten Rumah Tangga & 0 & 0 \\
Lainnya & 0 & 0 \\
Total & 111 & 100 \\
\hline
\end{tabular}

Tabel 8. Jumlah kasus KDRT di Kota Manado Tahun 2018-2019 menurut status pendampingan korban saat pelaporan

\begin{tabular}{lcc}
\hline \multicolumn{1}{c}{ Status Pendampingan } & Jumlah & \% \\
\hline Didampingi oleh & & \\
Lembaga Non Pemerintahan & 10 & 9 \\
Pengacara & 13 & 12 \\
Keluarga & 70 & 63 \\
Lainnya & 18 & 16 \\
Tidak didampingi & 0 & 0 \\
Total & 111 & 100 \\
\hline
\end{tabular}

Tabel 9. Jumlah kasus KDRT di Kota Manado Tahun 2018-2019 menurut selang waktu antara kejadian dan pelaporan

\begin{tabular}{lcc}
\hline \multicolumn{1}{c}{ Selang Waktu } & Jumlah & \% \\
\hline$<1$ minggu setelah kejadian & 92 & 83 \\
$>1$ minggu setelah kejadian & 19 & 17 \\
Total & 111 & 100 \\
\hline
\end{tabular}


Tabel 10. Jumlah kasus KDRT di Kota Manado tahun 2018-2019 menurut daerah tempat kejadian

\begin{tabular}{lcc}
\hline \multicolumn{1}{c}{ Kecamatan } & Jumlah & \% \\
\hline Wenang & 11 & 10 \\
Sario & 14 & 13 \\
Wanea & 11 & 10 \\
Tikala & 10 & 9 \\
Malalayang & 12 & 11 \\
Mapanget & 7 & 6 \\
Singkil & 12 & 11 \\
Tuminting & 11 & 10 \\
Bunaken & 8 & 7 \\
Bunaken Kepulauan & 7 & 6 \\
Paal Dua & 8 & 7 \\
Total & 111 & 100 \\
\hline
\end{tabular}

\section{BAHASAN}

Hasil penelitian menunjukkan bahwa terjadi fluktuasi angka kasus KDRT, merujuk dari penelitian yang dilakukan di Rumah Sakit Bhayangkara Manado periode tahun 2012-2013 dengan 54 kasus KDRT $^{6}$ dan periode tahun 2015-2016 dengan 153 kasus. $^{4}$ Pada tahun 2018 berdasarkan data yang didapatkan di tempat yang berbeda yaitu di Polresta Manado dengan jumlah 66 kasus dan pada tahun 2019 dengan 45 kasus, dengan jumlah total kasus yang dilaporkan pada kedua tahun 2018-2019 ialah 111 kasus. Walaupun sempat terjadi peningkatan jumlah kasus sebanyak $64,7 \%$ dan terjadi penurunan jumlah kasus sebanyak $27,4 \%$ tetapi penelitian ini mendapatkan bahwa lebih cenderung terjadi peningkatan sebanyak 51,3\% antara angka kasus KDRT yang terjadi pada tahun 2012-2013 dengan jumlah kasus pada tahun 2018-2019; dan hanya terjadi penurunan sebanyak $27,4 \%$ dari jumlah kasus pada tahun 2015-2016.

Jumlah kasus KDRT yang terjadi di Kota Manado masih terbilang cukup sedikit bila dibandingkan dengan kota lain di Indonesia. Penelitian oleh Setiawan et $\mathrm{al}^{7}$ yang dilaksanakan pada tahun 2018 melaporkan bahwa di Kota Semarang pada tahun 20152016 terdapat 206 kasus terlapor. Di Jakarta, KDRT semakin meningkat dari tahun ke tahun. Pada tahun 2001 tercatat sebanyak 258 kasus KDRT, kemudian 226 kasus pada tahun 2002, 272 kasus pada tahun 2003, 328 kasus pada tahun 2004, 455 kasus pada tahun 2005, dan terus meningkat hingga sekarang. ${ }^{8}$ Hal ini mungkin disebabkan oleh jumlah dan laju pertumbuhan penduduk yang berbeda. Berdasarkan Badan Pusat Statistik (BPS) Kota Semarang, ditemukan bahwa laju penduduk geometrisnya ialah 1,66\% pada tahun 2016 sedangkan di Jakarta, berdasarkan BPS Provinsi DKI Jakarta, laju penduduk geometrisnya pada tahun 2000-2005 ialah 1,52\%. Bila dibandingkan dengan data yang didapatkan dalam BPS kota Manado pada tahun 2016, laju pertumbuhan penduduk geometrisnya ialah 0,5\%, yang menunjukkan perbedaan cukup jauh dibandingkan dengan kedua kota besar tersebut. Melihat hal ini, dapat disimpulkan bahwa laju pertumbuhan penduduk merupakan salah satu faktor yang sangat berpengaruh terhadap angka kejadian KDRT dalam rumah tangga itu sendiri. ${ }^{9-11}$

Faktor yang dapat memengaruhi tingginya jumlah kasus KDRT antara lain ialah status sosial dan ekonomi rendah, pendidikan rendah, paradigma yang beredar di masyarakat berupa hubungan kekuasaan yang tidak seimbang, pernikahan usia dini, kekerasan yang sering dijadikan alat untuk menyelesaikan konflik, dan lain sebagainya. Faktor status sosial dan ekonomi yang rendah (Tabel 6) memperlihatkan bahwa yang banyak menjadi korban KDRT ialah 
korban yang tidak bekerja dengan jumlah 57 kasus $(51 \%)$ dari keseluruhan kasus. Hal ini mungkin disebabkan oleh rendahnya ekonomi yang memicu KDRT karena korban yang tidak bekerja. Pendidikan rendah kerap berhubungan dengan status ekonomi yang rendah dan pengetahuan yang rendah akan berdampak terjadinya KDRT. Banyak pelaku didominasi oleh pendidikan yang cukup rendah yaitu SLTP dengan jumlah 50 kasus $(45 \%)$ (Tabel 5). Kurangnya pengetahuan mengenai pentingnya mencegah terjadinya KDRT berakibat semakin banyak kasus KDRT yang dilakukan. Hal ini juga dapat dipengaruhi oleh jumlah penduduk yang memiliki tingkat pendidikan terkait. Data kependudukan BPS Kota Manado pada tahun 2019 menyatakan bahwa penduduk paling banyak memiliki tingkat pendidikan akhir SLTA dengan jumlah penduduk sebanyak 197.748 jiwa, sedangkan yang memiliki tingkat pendidikan terakhir SLTP pada posisi ketiga setelah Perguruan Tinggi dengan jumlah 49.842 jiwa. $^{9}$

Faktor paradigma yang beredar di masyarakat bahwa KDRT merupakan ranah personal, dapat diselesaikan dalam lingkungan keluarga tanpa ada pihak ketiga, atau menurunkan penilaian orang-orang mengenai sebuah rumah tangga, ditunjukkan dari masih kurangnya pelaporan untuk jenis kekerasan seksual, dan psikis. Hal ini sering disebabkan oleh korban yang malu melapor akan tindak kekerasan yang dialaminya. Faktor yang lain ialah hubungan kekuasaan yang tidak seimbang, yang sering disebabkan oleh perbedaan gender, kedudukan dalam keluarga, dan usia.

Perbedaan hubungan kekuasaan yang dipengaruhi dengan perbedaan jenis kelamin diperlihatkan dalam Tabel 2, 3, dan Tabel 7. Tabel 2 memperlihatkan data didominasi oleh korban berjenis kelamin perempuan dengan jumlah sebanyak 101 kasus (91\%) dan berhubungan dengan Tabel 3 yaitu pelaku yang didominasi oleh jenis kelamin laki-laki dengan jumlah kasus 101 kasus (91\%), status korban terbanyak ialah istri dari pelaku berjumlah 101 kasus $(91 \%)$ yang diperlihatkan dalam Tabel 7. Selain itu, Tabel 7 juga memperlihatkan hubungan kekuasaan yang dipengaruhi juga oleh keadaan fisik, yaitu 10 kasus dengan korban berjenis kelamin laki-laki dan jenis kekerasan fisik. Kekerasan yang dilakukan dengan korban yang sudah mengalami penyakit seperti stroke dan korban difabel. Hasil ini menunjukkan bahwa tidak menutup kemungkinan bahwa laki-laki juga dapat menjadi korban KDRT meskipun jumlah kasusnya sangat sedikit dibandingkan korban berjenis kelamin perempuan. Ketidakberdayaan korban seringkali dijadikan kesempatan oleh pelaku dalam melakukan tindak kekerasan.

Tabel 4 memperlihatkan bahwa kelompok usia yang paling banyak menjadi korban KDRT ialah usia 15-24 tahun dengan jumlah 43 kasus (39\%) dari keseluruhan kasus merujuk pada maraknya kasus KDRT yang terjadi dikarenakan usia pernikahan dini, yang berkaitan dengan Tabel 7 yang memperlihatkan bahwa korban terbanyak ialah yang berstatus sebagai istri pelaku. Selain itu terdapat juga 19 kasus (17\%) pada korban berusia 5-14 tahun yang merupakan ketiga terbanyak dari keseluruhan kasus, dengan status dari 19 korban ialah istri pelaku yang menikah pada usia 14 tahun dan disahkan berdasarkan kepercayaan dan adat istiadat yang berlaku di daerah mereka.

Kekerasan fisik masih mendominasi dari seluruh bentuk KDRT yang terjadi dari tahun ke tahun tercermin pada Tabel 1 yang memperlihatkan bahwa kekerasan fisik berjumlah 78 kasus (70\%) dari keseluruhan kasus dan sering dijadikan alat untuk menyelesaikan konflik dalam rumah tangga. Hal ini menunjukkan bahwa korban dalam kasus KDRT di Kota Manado sebagian besar mengalami kekerasan fisik. Tidak didapatkannya data mengenai pelaporan kekerasan seksual, dan psikis mungkin disebabkan oleh masih banyak korban yang malu atau mengurungkan niat untuk melaporkan kekerasan yang dialaminya karena stigma merusak hubungan rumah tangga dan menjaga nama baik yang merupakan stigma yang masih cukup kuat di Kota Manado dengan yang terbanyak terjadi di Kecamatan Sario (Tabel 10). Hal ini mungkin disebabkan oleh laju pertumbuhan dan kepadatan penduduk yang berbeda 
untuk setiap kecamatan. Selain jumlah kepadatan penduduk per rumah tangga, mungkin juga disebabkan oleh faktor ekonomi. Menurut data yang diambil dari BPS Kecamatan Sario pada tahun 2020, didapatkan bahwa hanya 2.863 penduduk dari 19.784 total penduduk keseluruhan Kecamatan Sario dengan status pekerjaan PNS (Pegawai Negeri Sipil), TNI (Tentara Nasional Indonesia), dan gabungan keduanya yang merupakan pekerjaan dengan gaji tetap. ${ }^{12}$

Tabel 9 memperlihatkan bahwa paling banyak korban melapor kurang dari satu minggu setelah kasus KDRT terjadi (83\%) dan paling banyak didampingi oleh keluarga (63\%) dari keseluruhan kasus. Hal ini menunjukkan bahwa banyak korban KDRT mulai menyadari betapa pentingnya untuk secepatnya melaporkan kasus kekerasan rumah tangga yang dialaminya, dikarenakan penatalaksanaan korban kasus KDRT harus dilakukan sesegera mungkin dan secara konprehensif, terpadu dan holistik terhadap gangguan-gangguan yang mungkin timbul baik fisik maupun psikis. ${ }^{13}$ Adanya berbagai prasangka, sikap masyarakat yang berdamai dan memandang KDRT sebagai suatu perilaku yang dapat diterima secara signifikan berkontribusi pada tingginya frekuensi dan luasnya bentuk KDRT.

\section{SIMPULAN}

Terjadi fluktuasi angka kasus KDRT dengan jenis kekerasan masih didominasi oleh kekerasan fisik dari tahun ke tahun. Pelaku KDRT terbanyak berjenis kelamin laki-laki dengan status sebagai suami korban. Tidak ditemukannya pelaporan kasus KDRT berupa kekerasan seksual dan psikis mungkin disebabkan oleh enggannya korban untuk melapor dikarenakan malu akan kasus KDRT yang dialaminya. Masyarakat sudah mulai mengetahui pentingnya untuk secepatnya melaporkan kasus KDRT yang dialaminya demi penanganan yang lebih memadai.

Penelitian ini memperlihatkan perlunya pengambilan data lebih dari satu sumber tempat agar dapat dilakukan perbandingan yang lebih baik dengan data lebih lengkap.

\section{Konflik Kepentingan}

Penulis menyatakan tidak terdapat konflik kepentingan dalam studi ini.

\section{DAFTAR PUSTAKA}

1. Presiden Republik Indonesia. Undang Undang Nomor 23 Tahun 2004 Tentang Kekerasan dalam Rumah Tangga.

2. Mallo NTS, Kristanto EG. Pola luka pada kekerasan dalam rumah tangga terhadap perempuan di RS Bhayangkara Manado periode 2013. e-CliniC. 2015;3(2):634-9.

3. Catatan Kekerasan terhadap Perempuan Tahun 2017. Jakarta 7 Maret 2018.

4. Lumente MA, Kristanto EG, Siwu JF. Keragaman kasus forensik klinik di RS Bhayangkara Tingkat III Manado dari sudut pandang SKDI 2012 periode Juli 2015Juni 2016. e-ClniC. 2017;5(1):51-6.

5. Susanti R. Paradigma baru peran dokter dalam pelayanan kedokteran forensik. Majalah Kedokteran Andalas. 2012;36(2):145-54.

6. Mantiri SIE, Siwu FJ, Kristanto EG. Hubungan antara usia waktu menikah dengan kejadian kekerasan dalam rumah tangga di Manado periode September 2012Agustus 2013. e-CliniC. 2014;2(1):1-9.

7. Setiawan CN, Bhima SKL, Dhanardhono T. Faktor-faktor yang memengaruhi kejadian kekerasan dalam rumah tangga dan pelaporan pada pihak kepolisian. Jurnal Kedokteran Diponegoro. 2018;7(1): 127-39.

8. Utama WT, Sukohar A. Kekerasan dalam rumah tangga: Laporan kasus. Juke Unila. 2015;5(9):55-60.

9. Badan Pusat Statistik Kota Manado. Kota Manado dalam Angka 2020. Katalog 1102001.7171. p. 99.

10. Badan Pusat Statistik Kota Semarang. Kota Semarang dalam Angka 2017. Katalog 1102001.3374. p. 27.

11. Badan Pusat Statistik Propinsi DKI Jakarta 2006. Katalog BPS 1403.31. p. 61.

12. Badan Pusat Statistik Kota Manado. Kecamatan Sario dalam Angka 2020. Katalog: 1102001.7171020.

13. Indrayana MT, Afandi D, Fatriah SH. The role of trans sectoral service in violance against women and children cases at Pekanbaru. Indonesian Journal of Legal and Forensic Sciences. 2012;2(3):45-7. 